\title{
PERILAKU BERKENDARA SEPEDA MOTOR PADA REMAJA BERUSIA DI BAWAH 17 TAHUN
}

\author{
Naomi Srie Kusumastutie \\ Politeknik Keselamatan Transportasi Jalan, Tegal, Indonesia
}

\begin{abstract}
Abstrak
Maraknya penggunaan sepeda motor pada remaja berusia di bawah usia untuk memiliki SIM (17 tahun) merupakan fenomena yang sangat memprihatinkan. Penelitian ini bertujuan untuk mengetahui gambaran mengenai perilaku berkendara sepeda motor pada remaja berusia di bawah 17 tahun di Kota Tegal. Teknik pengumpulan data yang digunakan adalah pmeberian kuesioner kepada siswa berusia di bawah 17 tahun di SMPN 1 Kota Tegal, SMAN 1 Kota Tegal, dan SMAN 5 Kota Tegal. Teknik analisis data yang digunakan adalah analisis deskriptif. Hasil dari penelitian ini adalah mayoritas responden mengaku telah dapat mengendarai sepeda motor dan hal ini pun lazim terjadi di lingkungan tempat tinggalnya, terdapat kecenderungan usia untuk mengendarai sepeda motor untuk pertama kalinya semakin muda, responden laki-laki dan berusia maupun tingkat usia lebih tinggi lebih berikisi, dan responden yang belum bisa mengendari sepeda motor cenderung untuk tidak berkeinginan untuk belajar menegendarainya pada saat ini.
\end{abstract}

Kata kunci: stres kerja, pengemudi bus, macet

\section{PENDAHULUAN}

Berdasarkan Global Status Report On Road Safety (WHO, 2009) kecelakaan lalu lintas menjadi penyebab kematian terbesar nomor sepuluh di dunia pada tahun 2004. Diprediksi pada tahun 2030 kecelakaan lalu lintas akan menjadi lima besar penyebab kematian di dunia.

Jika dilihat dari segi usia korban, kelompok usia muda menjadi korban terbesar kecelakaan lalu lintas, yaitu peringkat kedua untuk usia 5-14 tahun dan peringkat pertama untuk kelompok usia 15-29 tahun. Data ini menunjukkan tingginya risiko remaja untuk terlibat kecelakaan lalu lintas.

Data dari NHTSA (2008) sejalan dengan data di atas. Dilaporkan bahwa di Amerika Serikat pada tahun 2008, tercatat 5.864 pengemudi usia 15-20 tahun terlibat kecelakaan fatal. Walaupun terdapat penurunan jumlah dari tahun-tahun sebelumnya, namun angka kecelakaan yang dialami oleh pengemudi usia remaja masihlah sangat tinggi. Dari data tersebut, kecelakaan sepeda motor menjadi penyebab utama kematian pada kelompok usia 15-20 tahun, dengan korban meninggal sebanyak 2.739 orang dan terluka sebanyak 228.000 orang. 
Pada kecelakaan lalu lintas yang melibatkan pengendara sepeda motor usia 15-20 tahun tersebut, sebanyak 30\% tidak memliki SIM atau memiliki masalah SIM. Selain itu juga diketemukan bahwa $31 \%$ pengendara yang meninggal dalam kondisi mabuk. Terkait dengan penggunaan helm sebanyak 35\% pengendara usia 15-20 tahun yang mengalami luka berat tidak menggunakan helm (NHTSA, 2008).

Bentuk pelanggaran lalu lintas yang sering dilakukan oleh remaja adalah sebagai berikut (NHTSA, 2008):
a. Kebut-kebutan
b. Tidak memiliki atau membawa SIM saat mengemudi
c. Melanggar rambu-rambu lalu lintas
d. Tidak menggunakan helm
e. Menggunakan HP saat mengemudi
f. Konsumsi alkohol saat mengemudi
g. Tidak menggunakan safety belt
h. Mengemudi agresif

Salah satu syarat untuk dapat mengajukan SIM C adalah berusia minimal 17 tahun (UU No 22 Tahun 2009 pasal 81 ayat 2). Satu fenomena baru, terkait perilaku berkendara sepeda motor, yang banyak terjadi di lingkungan kita adalah para remaja usia di bawah usia untuk dapat memiliki SIM. Lebih memprihatinkan lagi bahwa anak-anak usia sekolah dasar pun kini telah jamak menggunakan sepeda motor dalam aktivitasnya sehari-hari. Dengan semakin mudanya remaja menggunakan sepeda motor maka akan semakin tinggilah risiko yang akan dihadapi.

Untuk itu penelitian ini bertujuan untuk mengetahui gambaran mengenai perilaku berkendara sepeda motor pada remaja berusia di bawah 17 tahun di Kota Tegal. Penelitian lanjutan untuk penelitian ini adalah penyusunan intervensi terhadap perilaku berkendara sepeda motor pada remaja berusia di bawah 17 tahun.

\section{METODE}

\subsection{Lokasi Penelitian}

Penelitian ini berlokasi di Kota Tegal, yaitu SMPN 1 Kota Tegal, SMAN 1 Kota Tegal, dan SMAN 5 Kota Tegal. 


\subsection{Subjek Penelitian}

Sesuai dengan tujuan penelitian ini, maka populasi dalam penelitian ini adalah siswa berusia di bawah 17 tahun di SMPN 1 Kota Tegal, SMAN 1 Kota Tegal, dan SMAN 5 Kota Tegal. Pemilihan sampel menggunakan teknik purposive sampling, dengan mengambil dua kelas siswa SMPN 1 Kota Tegal dan masing-masing satu kelas untuk SMAN 1 Kota Tegal dan SMAN 5 Kota Tegal.

\subsection{Metode Pengumpulan dan Analisis Data}

Pengumpulan data dalam penelitian ini menggunakan kuesioner yang terdiri dari tiga bagian, yaitu: identitas responden, gambaran perilaku berkendara, dan elicitation study sebagai salah satu tahap dalam penyusunan kuesioner TPB untuk mengungkap salient belief responden. Dalam artikel ini hanya akan dibahas mengenai gambaran perilaku berkendara.

Daftar pertanyaan yang digunakan untuk mengungkap gambaran perilaku berkendara adalah sebagai berikut:

a. Apakah Anda sudah bisa mengendarai sepeda motor?

b. Pertanyaan untuk responden yang sudah bisa mengendarai sepeda motor:

1) Pada usia berapa Anda belajar mengendarai sepeda motor untuk yang pertama kalinya?

2) Seberapa sering Anda mengendarai sepeda motor dalam satu minggu?

3) Seberapa jauh jarak yang biasa Anda tempuh dengan mengendarai sepeda motor?

4) Seberapa banyak anak usia dibawah 17 tahun di lingkungan tempat tinggal Anda yang telah bisa mengendarai sepeda motor?

c. Pertanyaan untuk responden yang belum bisa mengendarai sepeda motor:

1) Apakah Anda ingin belajar mengendarai sepeda motor saat ini?

2) Seberapa banyak anak usia dibawah 17 tahun di lingkungan tempat tinggal Anda yang telah bisa mengendarai sepeda motor?

Teknik analisa yang digunakan adalah analisis deskripstif kuantitatif, sehingga akan didapatkan gambaran mengenai perilaku berkendara sepeda motor pada remaja yang berusia di bahwah 17 tahun di Kota Tegal. 


\section{HASIL DAN PEMBAHASAN}

\subsection{Profil Responden}

Survei pada penelitian ini dilakukan di tiga lokasi, yaitu SMAN 1 Kota Tegal, SMAN 5 Kota Tegal, dan SMPN 1 Kota Tegal. Sesuai dengan populasi pada penelitian ini, yaitu remaja usia di bawah 17 tahun, maka untuk siswa SMA yang menjadi responden penelitian adalah khusus kelas X, sedangkan untuk siswa SMP meliputi kelas VII dan VII. Kebetulan pada saat pengambilan data siswa kelas IX SMPN 1 Kota Tegal sedang mengikuti kegiatan yang tidak bisa ditinggalkan, sehingga pada penelitian ini tidak dapat menyertakan sampel siswa kelas IX. Namun demikian responden yang ada dinilai sudah cukup representatif. Keseluruhan jumlah responden adalah 122 siswa. Profil responden dapat dilihat pada Tabel 1.

Tabel 1. Profil responden

\begin{tabular}{|l|l|c|c|}
\hline \multicolumn{2}{|c|}{ Kriteria } & Jumlah & Prosentase \\
\hline \multirow{3}{*}{ Lokasi } & SMPN 1 & 60 & $49,2 \%$ \\
\cline { 2 - 4 } & SMAN 1 & 30 & $24,6 \%$ \\
\cline { 2 - 4 } & SMAN 5 & 32 & $26,2 \%$ \\
\hline \multirow{2}{*}{ Sekolah } & SMP & 60 & $49,2 \%$ \\
\cline { 2 - 4 } & SMA & 62 & $50,8 \%$ \\
\hline \multirow{3}{*}{ Kelas } & VII & 31 & $25,4 \%$ \\
\cline { 2 - 4 } & VIII & 29 & $23,8 \%$ \\
\cline { 2 - 4 } & $\mathrm{X}$ & 62 & $50,8 \%$ \\
\hline \multirow{3}{*}{ Jenis Kelamin } & Laki-laki & 53 & $43,4 \%$ \\
\cline { 2 - 4 } & Perempuan & 69 & $56,6 \%$ \\
\hline \multirow{5}{*}{ Usia } & 11 tahun & 2 & $1,6 \%$ \\
\cline { 2 - 4 } & 12 tahun & 22 & $18 \%$ \\
\cline { 2 - 4 } & 13 tahun & 30 & $24,6 \%$ \\
\cline { 2 - 4 } & 14 tahun & 14 & $11,5 \%$ \\
\cline { 2 - 4 } & 15 tahun & 45 & $36,9 \%$ \\
\cline { 2 - 4 } & 16 tahun & 9 & $7,4 \%$ \\
\hline
\end{tabular}

Berdasarkan Tabel 1 di atas dapat dilihat bahwa proporsi responden antara siswa SMP dan SMA berimbang, yaitu sejumlah 60 dan 62 orang (49,2\% dan 50,8\%). Responden didominasi oleh perempuan, yaitu sejumlah 69 orang (56,6\%). Rentang usia responden dari 11 tahun sampai dengan 16 tahun, dengan mayoritas responden berusia 15 tahun, yaitu sejumlah 45 orang (36\%). Sebaran usia dan jenis kelamin responden di setiap lokasi dapat dilihat pada Tabel 2. 
Tabel 2. Sebaran usia dan jenis kelamin responden berdasarkan lokasi penelitian

\begin{tabular}{|c|c|c|c|c|}
\hline \multirow{2}{*}{ Lokasi } & \multirow{2}{*}{ Usia } & \multicolumn{2}{|c|}{ Jenis kelamin (org) } & Total \\
\cline { 3 - 4 } & & Laki-laki & Perempuan & (org) \\
\hline \multirow{3}{*}{ SMPN 1 } & 11 th & 0 & 2 & 2 \\
\cline { 2 - 4 } & 12 th & 9 & 13 & 22 \\
\cline { 2 - 4 } & 13 th & 15 & 15 & 30 \\
\cline { 2 - 4 } & 14 th & 3 & 3 & 6 \\
\hline \multirow{3}{*}{ SMAN 1 } & 14 th & 3 & 0 & 3 \\
\cline { 2 - 4 } & 15 th & 9 & 15 & 24 \\
\cline { 2 - 4 } & 16 th & 1 & 2 & 3 \\
\hline \multirow{3}{*}{ SMAN 5 } & 14 th & 3 & 2 & 21 \\
\cline { 2 - 5 } & 15 th & 9 & 12 & 6 \\
\cline { 2 - 5 } & 16 th & 1 & 5 & \\
\hline
\end{tabular}

Responden di lokasi SMPN 1 Kota Tegal berusia antara 11 tahun sampai dengan 14 tahun. Mayoritas responden berusia 13 tahun, kemudian disusul oleh usia 12 tahun. Proporsi antara laki-laki dan perempuan pada tiap usia cukup berimbang, kecuali pada usia 11 tahun hanya ada responden berjenis kelamin perempuan. Responden di SMAN 1 Kota Tegal dan SMAN 5 Kota Tegal memiliki karakteritsik relatif sama. Kisaran usia responden antara 14 tahun sampai dengan 16 tahun, dengan mayoritas berusia 14 tahun. Proporsi jenis kelamin juga relatif berimbang. Jika digambarkan dalam grafik, maka sebaran usia dan jenis kelamin responden berdasarkan lokasi penelitian sebagaimana dapat dilihat pada Gambar 1 .
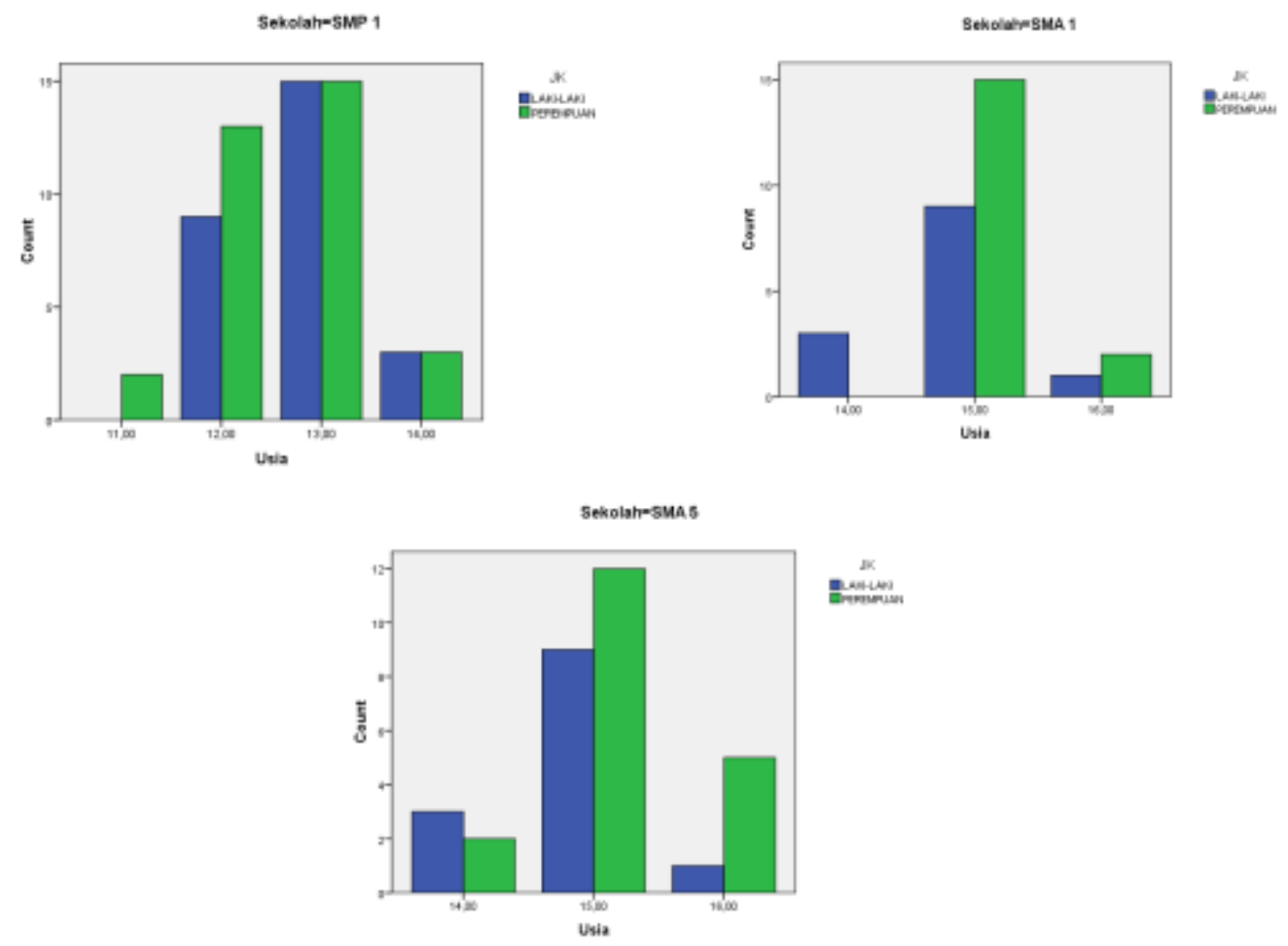

Gambar 1. Sebaran usia dan jenis kelamin responden berdasarkan lokasi penelitian 


\subsection{Perilaku Berkendara Sepeda Motor}

\subsubsection{Kemampuan Mengendarai Sepeda Motor}

Berdasarkan hasil survei terhadap 122 orang siswa SMP dan SMA di Kota Tegal yang berusia di bawah 17 tahun dalam penelitian ini, dapat diketahui bahwa mayoritas responden telah dapat mengendarai sepeda motor. Pada pertanyaan, "Apakah Anda sudah bisa mengendarai sepeda motor?", sebanyak 98 (80,3\%) responden yang menjawab "sudah", dan 24 (19,7\%) responden menjawab "belum". Berdasarkan jenis kelamin responden dapat diketahui bahwa laki-laki cenderung sudah dapat berkendara dibandingkan perempuan, hal ini dapat dilihat pada Tabel 3.

Tabel 3. Kecenderungan berkendara sepeda motor berdasarkan jenis kelamin

\begin{tabular}{|c|c|c|c|c|}
\hline \multirow{2}{*}{$\begin{array}{c}\text { Jenis } \\
\text { Kelamin }\end{array}$} & \multicolumn{3}{|c|}{ Apakah sudah bisa mengendarai sepeda motor } \\
\cline { 2 - 5 } & \multicolumn{2}{|c|}{ Sudah } & \multicolumn{2}{c|}{ Belum } \\
\cline { 2 - 5 } & Jml & $\%$ & Jml & $\%$ \\
\hline Laki-laki & 47 & 38,5 & 6 & 4,9 \\
\hline Perempuan & 51 & 41,8 & 18 & 14,8 \\
\hline Total & 98 & 80,3 & 24 & 19,7 \\
\hline
\end{tabular}

Jika dilihat dari perbandingan antara yang sudah dapat dan yang belum dapat mengendarai sepeda motor diketahui bahwa laki-laki memiliki kecenderungan lebih tinggi untuk dapat mengendarai sepeda motor dibandingkan perempuan. Lebih rinci Tabel 4 menunjukkan kecenderungan tersebut jika dilihat dari jenis kelamin dan lokasi penelitian.

Tabel 4. Kecenderungan berkendara sepeda motor berdasarkan jenis kelamin dan lokasi penelitian

\begin{tabular}{|c|c|c|c|c|c|}
\hline \multirow{2}{*}{ Lokasi } & \multirow{2}{*}{$\begin{array}{c}\text { Jenis } \\
\text { Kelamin }\end{array}$} & \multicolumn{3}{|c|}{ Apakah sudah bisa mengendarai sepeda motor } \\
\cline { 3 - 6 } & & \multicolumn{2}{|c|}{ Sudah } & \multicolumn{2}{c|}{ Belum } \\
\cline { 3 - 6 } & Laki-laki & 13 & 43,3 & 0 & 0 \\
\hline SMAN 1 & Perempuan & 16 & 53,3 & 1 & 3,3 \\
\hline & Laki-laki & 12 & 37,5 & 1 & 3,1 \\
\hline SMAN 5 & Perempuan & 18 & 56,2 & 1 & 3,1 \\
\hline & Laki-laki & 22 & 36,7 & 5 & 8,3 \\
\hline SMPN 1 & Lerempuan & 17 & 28,3 & 16 & 26,7 \\
\hline & Peryyyyy \\
\hline
\end{tabular}

Berdasarkan Tabel 4.4 dapat dilihat bahwa responden yang duduk di bangku SMA memiliki kecenderungan lebih tinggi untuk dapat mengendarai sepeda motor dibandingkan dengan responden yang duduk di bangku SMP. Responden perempuan yang duduk di bangku SMP memiliki kecenderungan belum dapat mengendarai sepeda 
motor. Jika dilihat lebih lanjut, dapat diketahui bahwa responden di kelas VII cenderung belum dapat mengendarai sepeda motor dibandingkan dengan kelas yang lain, seperti yang ditunjukkan oleh Gambar 2.
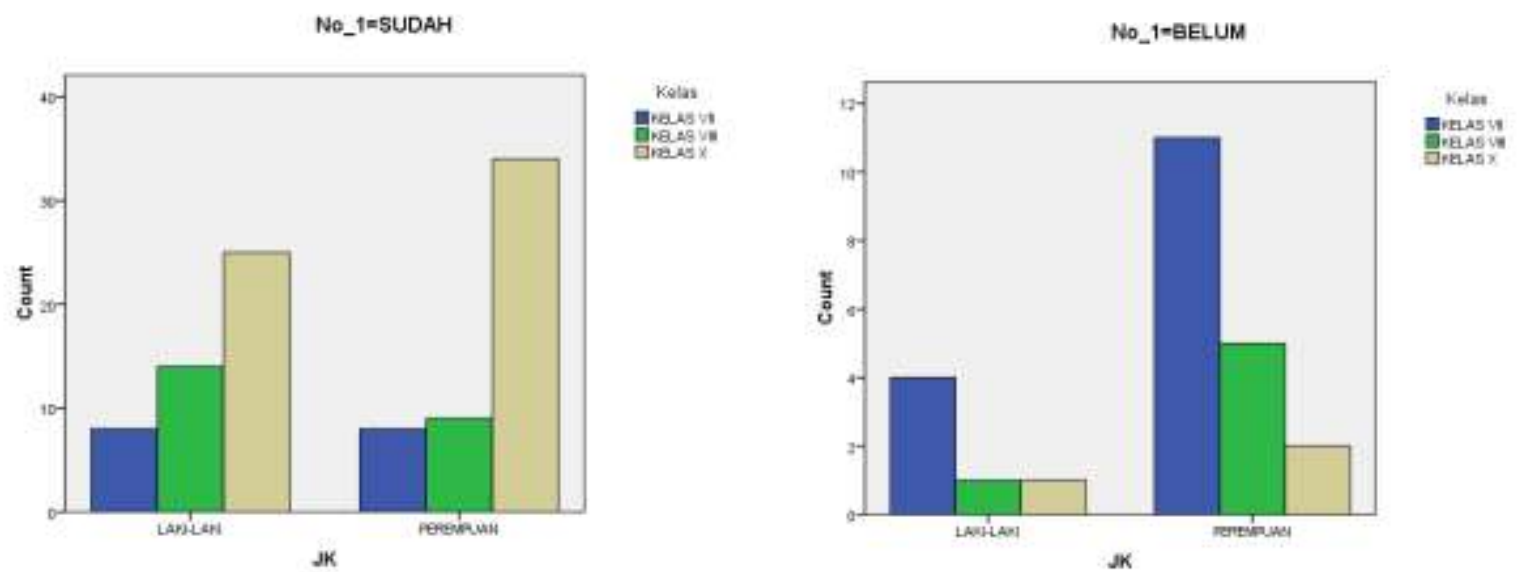

Gambar 2. Kecenderungan berkendara sepeda motor berdasarkan jenis kelamin dan kelas

Berdasarkan Gambar 4.2 diketahui bahwa kelas VII memiliki proporsi responden yang belum dapat mengendarai sepeda motor relatif lebih tinggi dibanding dengan kelas yang lain.

\subsubsection{Usia Saat Belajar Mengendarai Sepeda Motor Untuk yang Pertama Kalinya}

Kepada responden yang telah dapat mengendarai sepeda motor juga ditanyakan pada usia berapa responden belajar mengendarai sepeda motor untuk yang pertama kalinya. Dari 98 responden yang sudah dapat mengendarai sepeda motor, mayoritas menjawab belajar mengendarai sepeda motor untuk pertama kalinya pada usia antara 12 sampai dengan 13 tahun (masing-masing 28 orang atau 28,6\%), kemudian disusul usia 14 tahun (20 orang atau 20,4\%). Kecenderungan usia responden saat belajar sepeda motor untuk yang pertama kalinya dapat dilihat pada Gambar 3.

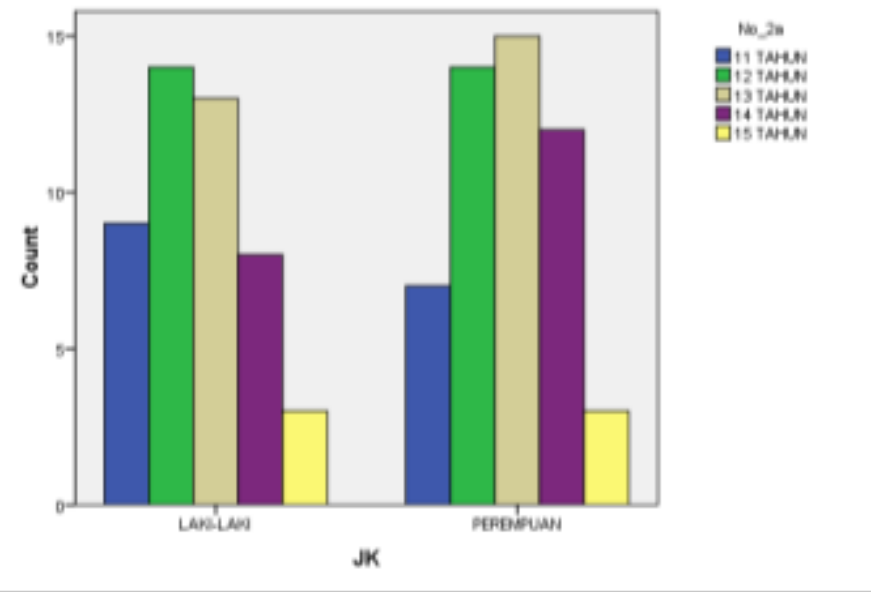

Gambar 3. Usia responden saat belajar sepeda motor untuk yang pertama kalinya 
Berdasarkan Gambar 3 di atas, dapat dilihat bahwa responden laki-laki belajar mengendarai sepeda motor pada usia yang lebih muda dibanding dengan responden perempuan. Usia tertinggi untuk belajar mengendarai sepeda motor ada pada usia 12 tahun untuk responden laki-laki dan 13 tahun untuk responden perempuan, setelah usia tersebut mengalami penurunan. Selain itu terdapat kecenderungan semakin mudanya usia untuk belajar mengendarai sepeda motor untuk yang pertama kalinya, seperti yang terlihat pada Gambar 4 dan Gambar 5.

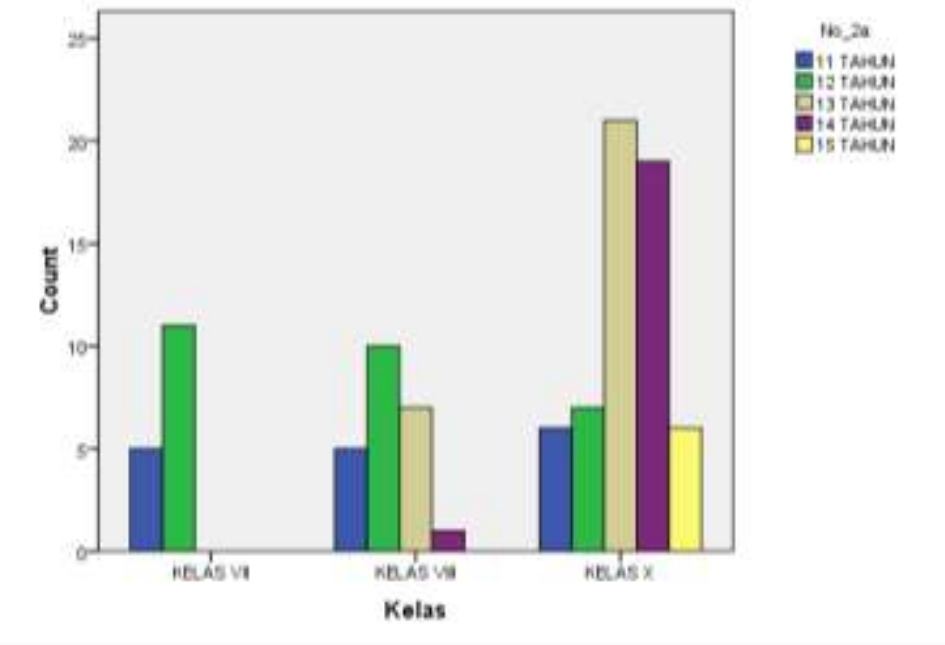

Gambar 4. Usia responden saat belajar sepeda motor untuk yang pertama kalinya berdasarkan kelas

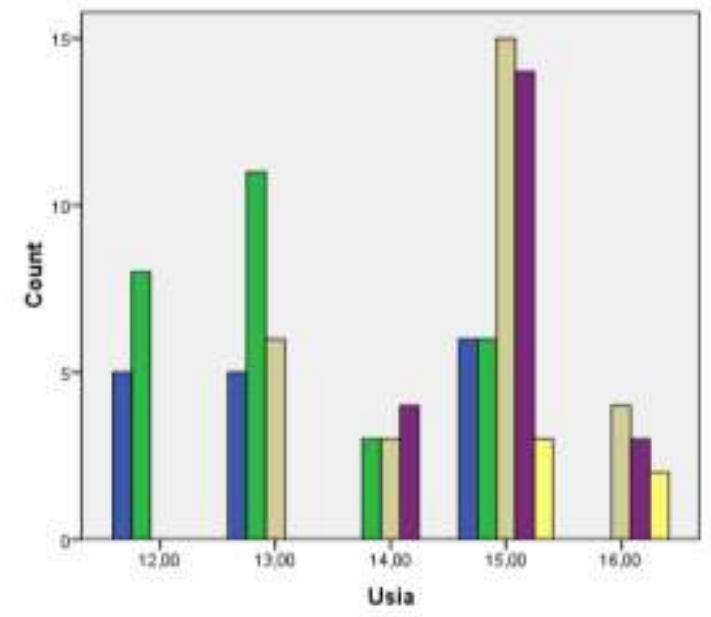

Gambar 5. Usia responden saat belajar sepeda motor untuk yang pertama kalinya berdasarkan usia responden

Gambar 4 menunjukkan jumlah responden yang pertama kali belajar mengendarai sepeda motor pada usia 11 dan 12 tahun mengalami peningkatan berdasarkan kelas. Responden dari kelas $X$ yang pertama kali belajar mengendarai sepeda motor pada usia 11 dan 12 tahun masing-masing sebanyak 6 dan 7 orang, responden dari kelas VIII sebanyak 5 dan 10 orang, sedangkan responden dari kelas VII sebanyak 5 dan 11 
orang. Indikasi kecenderungan semakin mudanya usia untuk belajar sepeda motor juga diperkuat oleh Gambar 5.

Gambar 5 menunjukkan bahwa responden berusia 16 tahun pertama kali belajar mengendarai sepeda motor pada usia 13 tahun, sedangkan responden dengan usia lebih muda pertama kali belajar mengendarai sepeda motor pada usia 11 tahun. Selain itu jumlah responden yang belajar mengendarai sepeda motor untuk yang pertama kalinya pada usia 12 tahun mengalami peningkatan pada usia responden yang lebih muda yaitu 12 dan 13 tahun. Prosentase usia responden saat belajar sepeda motor untuk yang pertama kalinya dapat dilihat pada Tabel 5 .

Tabel 5. Usia responden saat belajar sepeda motor untuk yang pertama kalinya berdasarkan kelas dan usia

\begin{tabular}{|c|c|c|c|c|c|c|c|}
\hline \multirow{2}{*}{\multicolumn{2}{|c|}{ Kriteria }} & \multicolumn{6}{|c|}{$\begin{array}{c}\text { Usia saat belajar sepeda motor untuk yang pertama } \\
\text { kalinya }\end{array}$} \\
\hline & & 11 th & 12 th & 13 th & 14 th & 15 th & 16 th \\
\hline \multirow{3}{*}{-Kelas } & VII & $5,1 \%$ & $11,2 \%$ & - & - & - & - \\
\hline & VIII & $5,1 \%$ & $10,2 \%$ & $7,1 \%$ & $1,0 \%$ & $0 \%$ & - \\
\hline & $X$ & $6,1 \%$ & $7,1 \%$ & $21,4 \%$ & $19,4 \%$ & $6,1 \%$ & - \\
\hline \multirow{5}{*}{$\begin{array}{l}\text { Usia } \\
\text { responden }\end{array}$} & 12 th & $5,1 \%$ & $8,2 \%$ & - & - & - & - \\
\hline & 13 th & $5,1 \%$ & $11,2 \%$ & - & - & - & - \\
\hline & 14 th & - & $3,1 \%$ & $3,1 \%$ & $4,1 \%$ & $0 \%$ & - \\
\hline & 15 th & $6,1 \%$ & $6,1 \%$ & $15,3 \%$ & $14,3 \%$ & $3,1 \%$ & - \\
\hline & 16 th & - & - & $4,1 \%$ & $3,1 \%$ & $2,0 \%$ & - \\
\hline
\end{tabular}

\subsubsection{Frekuensi Mengendarai Sepeda Motor Dalam Satu Minggu}

Selanjutnya responden yang telah dapat mengendarai sepeda motor diberi pertanyaan mengenai frekuensi mengendarai sepeda motor dalam satu minggunya. Secara keseluruhan mayoritas responden mengendarai sepeda motor lebih dari empat kali dalam seminggu, yaitu sebanyak 42 responden (42,9\%). Frekuensi mengendarai sepeda motor dalam satu minggu berdasarkan jenis kelamin, sekolah, kelas, dan usia responden dapat dilihat pada Tabel 6 . 
Tabel 6. Frekuensi mengendarai sepeda motor dalam satu minggu

\begin{tabular}{|c|c|c|c|c|c|}
\hline \multirow{2}{*}{\multicolumn{2}{|c|}{ Kriteria }} & \multicolumn{4}{|c|}{$\begin{array}{c}\text { Frekuensi mengendarai sepeda motor } \\
\text { dalam satu minggu }\end{array}$} \\
\hline & & $<1$ kali & $1-2$ kali & 3-4 kali & $>4$ kali \\
\hline \multirow{2}{*}{$\begin{array}{l}\text { Jenis } \\
\text { Kelamin }\end{array}$} & Laki-laki & 12 & 4 & 5 & 26 \\
\hline & Perempuan & 16 & 14 & 5 & 16 \\
\hline \multirow{2}{*}{ Sekolah } & SMP & 15 & 11 & 4 & 9 \\
\hline & SMA & 13 & 7 & 6 & 33 \\
\hline \multirow{3}{*}{ Kelas } & VII & 6 & 6 & 1 & 3 \\
\hline & VIII & 9 & 5 & 3 & 6 \\
\hline & $\mathrm{X}$ & 13 & 7 & 6 & 33 \\
\hline \multirow{5}{*}{$\begin{array}{l}\text { Usia } \\
\text { responden }\end{array}$} & 12 th & 5 & 5 & 1 & 2 \\
\hline & 13 th & 10 & 4 & 2 & 6 \\
\hline & 14 th & 1 & 2 & 2 & 5 \\
\hline & 15 th & 11 & 5 & 4 & 24 \\
\hline & 16 th & 1 & 2 & 1 & 5 \\
\hline Total & & 28 & 18 & 10 & 42 \\
\hline
\end{tabular}

Berdasarkan jenis kelamin responden dapat dilihat bahwa laki-laki cenderung untuk lebih sering mengendarai sepeda motor dibandingkan perempuan, yaitu sebanyak 26 responden yang menjawab lebih dari empat kali dalam seminggu. Berbeda dengan kecenderungan pada responden laki-laki, frekuensi mengendarai sepeda motor pada responden perempuan cenderung merata antara frekuensi jarang (kurang dari satu kali seminggu) dan sering (lebih dari empat kali seminggu). Kecenderungan ini juga dapat dilihat pada Gambar 6.

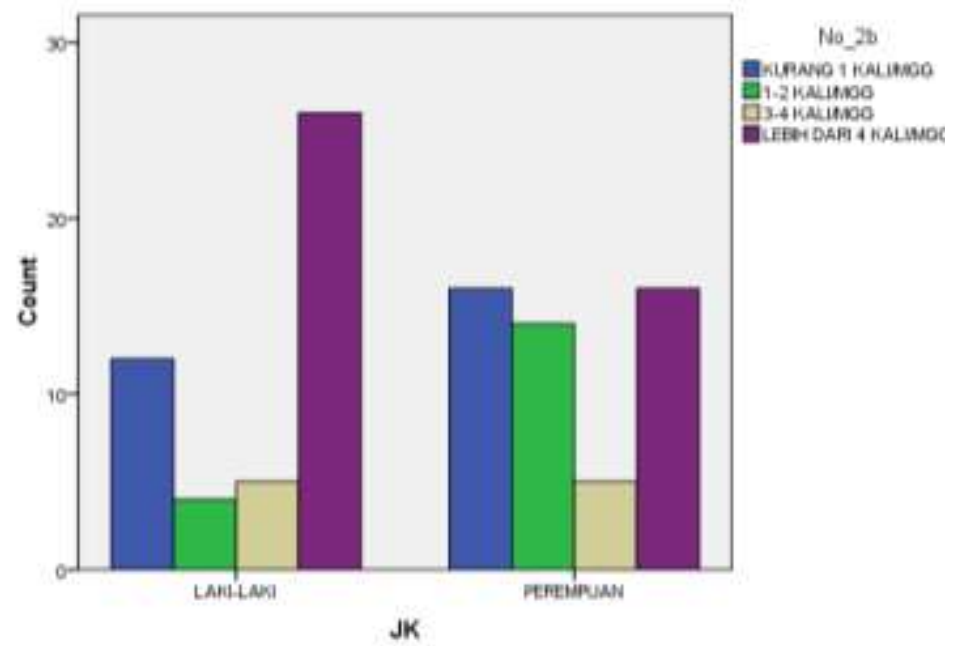

Gambar 6. Frekuensi mengendarai sepeda motor dalam satu minggu berdasarkan jenis kelamin

Responden yang duduk di bangku SMP cenderung memiliki frekuensi berkendara lebih rendah dibandingkan responden yang duduk di bangku SMA. Mayoritas responden yang duduk di bangku SMP, yaitu sebanyak 15 orang, mengendarai sepeda motor kurang dari satu kali dalam seminggu. Disusul dengan sebanyak 11 orang yang mengendarai sepeda motor satu sampai dua kali dalam seminggu. Responden yang 
duduk di bangku SMA cenderung sering mengendarai sepeda motor, yaitu sebanyak 33 orang mengendarai sepeda motor lebih dari empat kali dalam seminggu.

Jika dilihat dari kelas responden, responden pada kelas VII dan VIII cenderung lebih jarang mengendarai sepeda motor dalam satu minggu, yaitu pada frekuensi kurang dari satu kali (enam dan sembilan orang) dan satu sampai dua kali dalam seminggu (enam dan lima orang). Responden pada kelas $X$ cenderung sering mengendarai sepeda motor, yaitu 33 orang mengendarai sepeda motor lebih dari empat kali dalam seminggu.

Hal senada terlihat juga jika ditinjau dari usia responden. Responden dengan usia lebih muda cenderung untuk mengendarai sepeda motor lebih jarang dibanding dengan responden dengan usia lebih tua. Responden usia 12 tahun cenderung mengendarai sepeda motor kurang dari sekali atau antara satu dan dua kali dalam seminggu (masing-masing lima orang). Responden usia 13 tahun cenderung mengendarai sepeda motor kurang dari sekali seminggu, namun juga cenderung bertambah frekunsinya, yaitu lebih dari empat kali seminggu sebanyak empat orang. Pertambahan frekuensi berkendara semakin tampak seperti yang ditunjukkan oleh reponden usia 14 tahun yang mayoritas berkendara lebih dari empat kali dalam seminggu. Selanjutnya reponden dengan usia 15 tahun dan 16 tahun semakin menunjukkan ferkuensi yang tinggi dalam berkendara, yaitu lebih dari empat kali dalam seminggu. Kecenderungan frekuensi berkendara ini juga dapat dilihat pada Gambar 7 yang menunjukkan bahwa berdasar sekolah, kelas dan usia berturut-turut yang mengendai motor per minggu lebih dari empat kali adalah siswa SMA, kelas X, dan usia 15 tahun.
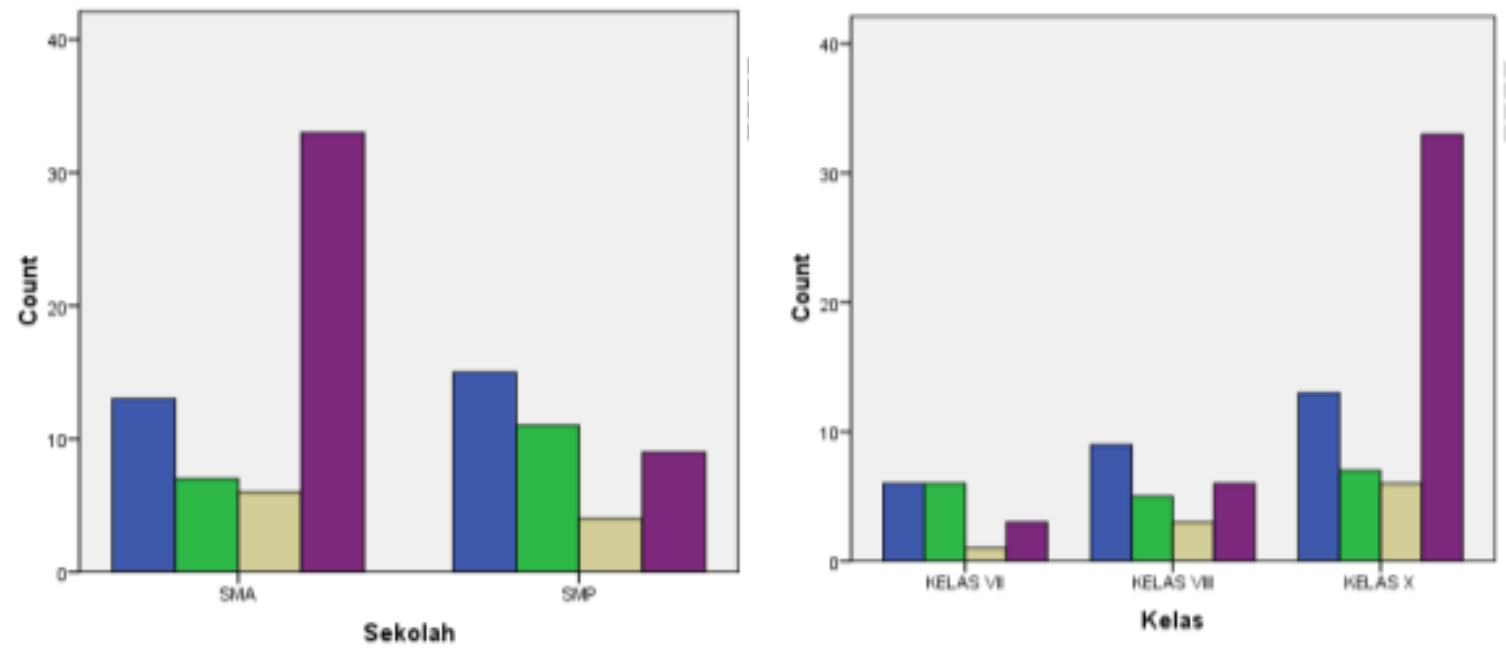


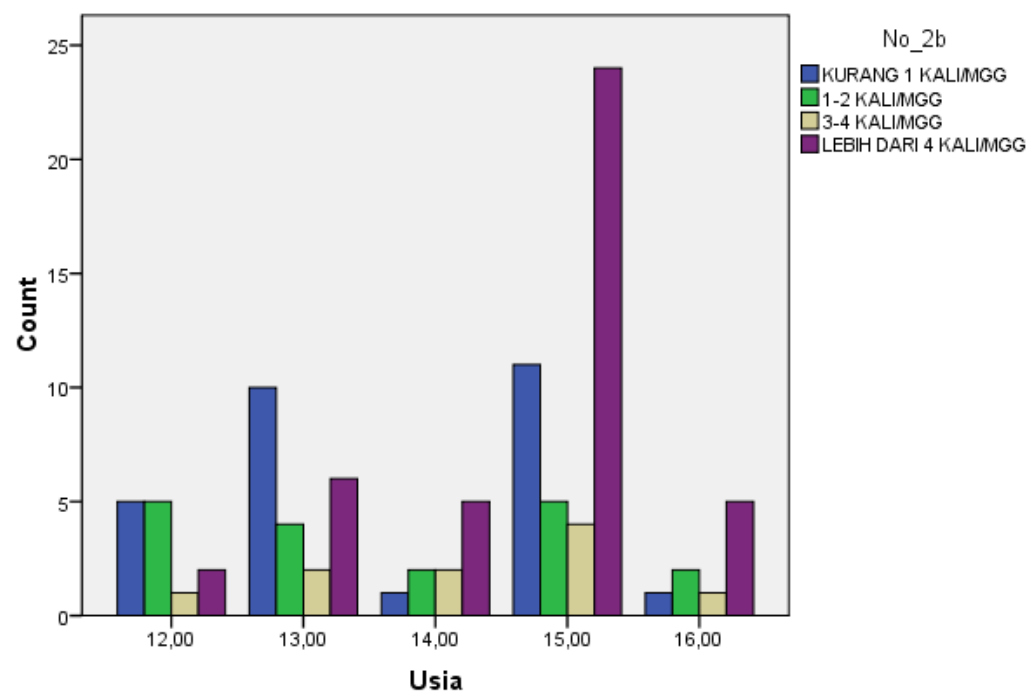

Gambar 7. Frekuensi mengendarai sepeda motor dalam satu minggu berdasarkan sekolah, kelas, dan usia responden

\subsubsection{Jarak Tempuh Dengan Mengendarai Sepeda Motor}

Selanjutnya, responden yang sudah dapat mengendarai sepeda motor juga diberi pertanyaan mengenai jarak yang ditempuh dengan mengendarai sepeda motor. Berdasarkan jawaban responden diketahui bahwa mayoritas responden sebanyak 56 orang $(57,1 \%)$ cenderung mengendarai sepeda motor di luar lingkungan tempat tinggal, sedangkan 42 orang $(42,9 \%)$ cenderung mengendarai sepeda motor di dalam lingkungan tempat tinggal. Kecenderungan Jarak tempuh dengan mengendarai sepeda motor dapat dilihat pada Tabel 7 .

Tabel 7. Jarak tempuh dengan mengendarai sepeda motor

\begin{tabular}{|c|c|c|c|}
\hline \multirow{2}{*}{\multicolumn{2}{|c|}{ Kriteria }} & \multicolumn{2}{|c|}{$\begin{array}{l}\text { Jarak tempuh dengan mengendarai } \\
\text { sepeda motor }\end{array}$} \\
\hline & & \multirow{2}{*}{$\begin{array}{c}\text { Di dalam } \\
\begin{array}{c}\text { lingkungan tempat } \\
\text { tinggal }\end{array} \\
17\end{array}$} & \multirow{2}{*}{$\begin{array}{c}\begin{array}{c}\text { Di luar } \\
\text { lingkungan } \\
\text { tempat tinggal }\end{array} \\
30\end{array}$} \\
\hline \multirow{2}{*}{$\begin{array}{l}\text { Jenis } \\
\text { Kelamin }\end{array}$} & Laki-laki & & \\
\hline & Perempuan & 25 & 26 \\
\hline \multirow{2}{*}{ Sekolah } & SMP & 27 & 12 \\
\hline & SMA & 15 & 44 \\
\hline \multirow{3}{*}{ Kelas } & VII & 13 & 3 \\
\hline & VIII & 14 & 9 \\
\hline & $X$ & 15 & 44 \\
\hline \multirow{5}{*}{$\begin{array}{l}\text { Usia } \\
\text { responden }\end{array}$} & 12 th & 11 & 2 \\
\hline & 13 th & 13 & 9 \\
\hline & 14 th & 3 & 7 \\
\hline & 15 th & 10 & 34 \\
\hline & 16 th & 5 & 4 \\
\hline Total & & 42 & 56 \\
\hline
\end{tabular}


Berdasarkan Tabel 7 dapat dilihat bahwa responden laki-laki cenderung memiliki daya jelajah menggunakan sepeda motor lebih luas daripada perempuan. Hal ini dapat dilihat dari kecenderungan responden laki-laki untuk berkendara sampai di luar lingkungan tempat tinggal, yaitu sebanyak 30 orang $(30,6 \%)$. Tidak demikian dengan responden perempuan, mereka tidak memiliki kecenderungan daya jelajah menggunakan sepeda motor. Kecenderungan mereka untuk berkendara di dalam maupun di luar lingkungan tempat tinggal relatif sama, yaitu 25 orang dan 26 orang. Gambar 8 menunjukkan jarak tempuh dengan mengendarai sepeda motor berdasarkan jenis kelamin reponden.

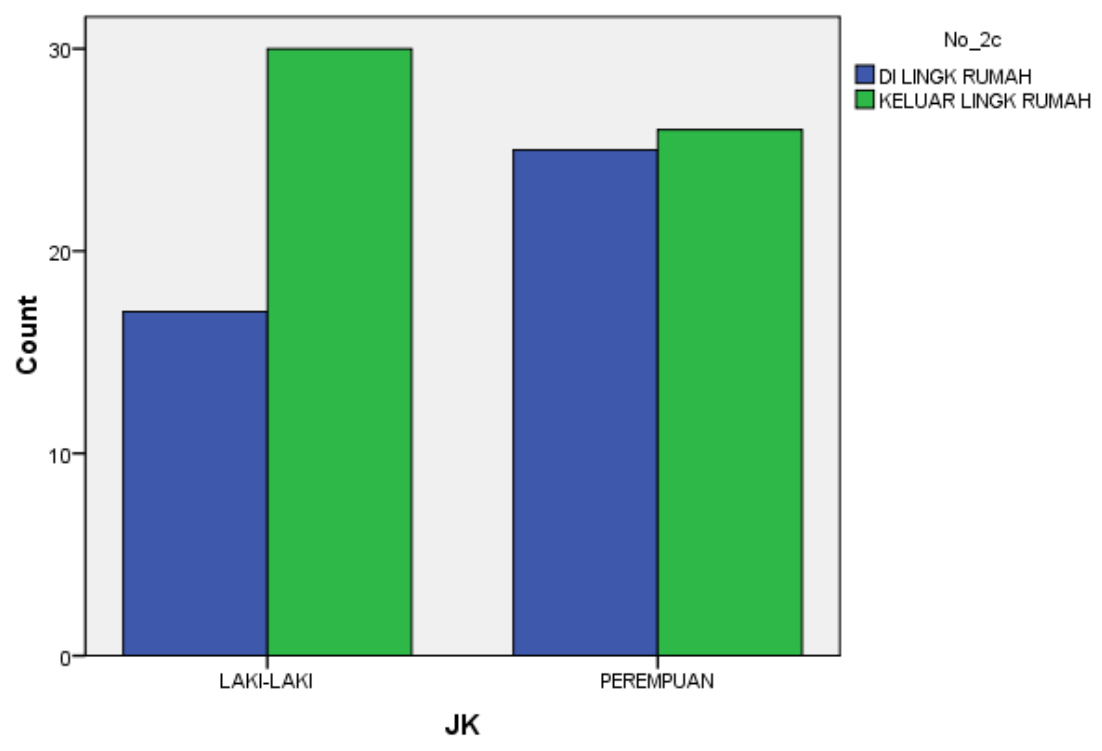

Gambar 8. Jarak tempuh dengan mengendarai sepeda motor berdasarkan jenis kelamin

Jika dilihat dari sekolah reponden, dapat diketahui bahwa siswa SMP cenderung berkendara di dalam lingkungan tempat tinggal (27 orang), sedangkan siswa SMA cenderung berkendara di luar lingkungan tempat tinggal (44 orang). Begitu pula jika ditinjau dari kelas responden, responden dari kelas lebih rendah cenderung untuk berkendara di dalam lingkungan tempat tinggal (mayoritas kelas VII sebanyak 13 orang dan kelas VIII sebanyak 14 orang) sedangkan responden dari kelas lebih tinggi cenderung untuk berkendara di luar lingkungan tempat tinggal (kelas $X$ sebanyak 44 orang). Jika dilihat dari usia responden, tampak bahwa reponden berusia 15 tahun memiliki kecednerungan tertinggi untuk berkendara di luar lingkungan tempat tinggal. Kecenderungan jarak tempuh dengan mengendarai sepeda motor berdasarkan sekolah, kelas, dan usia responden dapat lihat pada Gambar 9. 

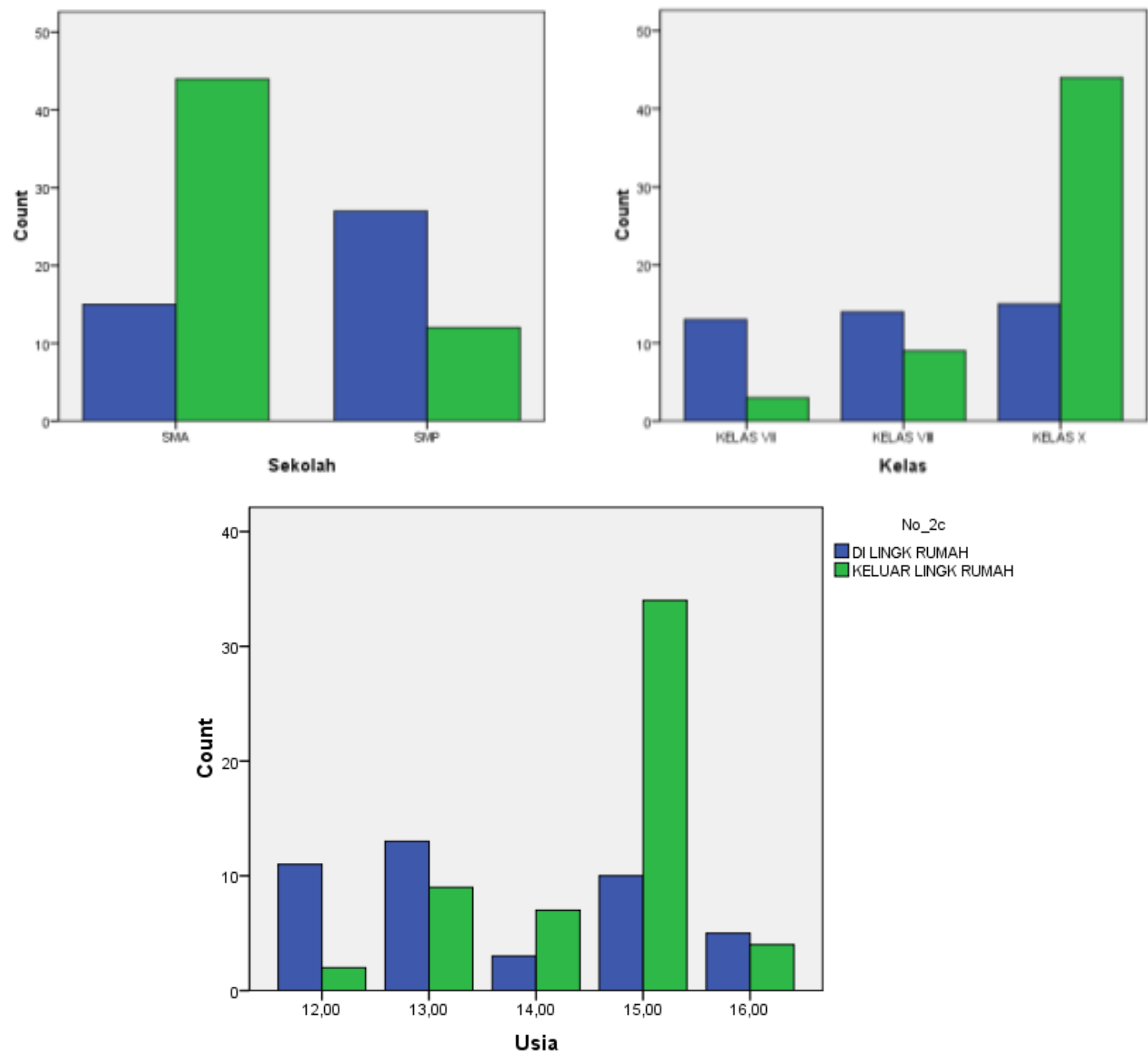

Gambar 9. Jarak tempuh dengan mengendarai sepeda motor berdasarkan sekolah, kelas, dan usia responden

\subsubsection{Keinginan untuk Belajar Mengendarai Sepeda Motor}

Responden yang belum bisa mengendarai sepeda motor sebanyak 24 orang, diberi pertanyaan terkait keinginan mereka untuk belajar mengendarai sepeda motor. Dari jawaban responden diketahui bahwa mayoritas tidak berkeinginan untuk belajar mengendarai sepeda motor saat ini (sejumlah 20 orang atau 83,3\%). Keinginan responden untuk belajar mengendarai sepeda motor dapat dilihat pada Tabel 7. 
Tabel 7. Keinginan untuk belajar mengendarai sepeda motor

\begin{tabular}{|c|c|c|c|}
\hline \multirow{2}{*}{\multicolumn{2}{|c|}{ Kriteria }} & \multicolumn{2}{|c|}{$\begin{array}{l}\text { Keinginan untuk belajar mengendarai } \\
\text { sepeda motor }\end{array}$} \\
\hline & & $\mathrm{Ya}$ & Tidak \\
\hline \multirow{2}{*}{$\begin{array}{l}\text { Jenis } \\
\text { Kelamin }\end{array}$} & Laki-laki & 1 & 5 \\
\hline & Perempuan & 3 & 15 \\
\hline \multirow{2}{*}{ Sekolah } & SMP & 2 & 19 \\
\hline & SMA & 2 & 1 \\
\hline \multirow{3}{*}{ Kelas } & VII & 1 & 14 \\
\hline & VIII & 1 & 5 \\
\hline & $X$ & 2 & 1 \\
\hline \multirow{6}{*}{$\begin{array}{l}\text { Usia } \\
\text { responden }\end{array}$} & 11 th & 0 & 2 \\
\hline & 12 th & 0 & 9 \\
\hline & 13 th & 2 & 6 \\
\hline & 14 th & 1 & 3 \\
\hline & 15 th & 1 & 0 \\
\hline & 16 th & 0 & 0 \\
\hline Total & & 4 & 20 \\
\hline
\end{tabular}

Berdasarkan jenis kelamin responden, baik laki-laki maupun perempuan sama-sama berkecenderungan untuk tidak ingin belajar mengendarai sepeda motor pada saat ini. Berdasarkan sekolah, mayoritas siswa SMP tidak ingin belajar mengendarai sepeda motor pada saat ini. Akan tetapi dari tiga orang siswa SMA yang belum dapat mengendarai sepeda motor, dua orang ingin belajar mengendarai sepeda motor saat ini. Jika dilihat dari usia, mayoritas responden relatif tidak ingin belajar mengendarai sepeda motor pada saat ini.

\subsubsection{Remaja Usia dibawah 17 Tahun di Lingkungan Tempat Tinggal yang Telah Bisa Mengendarai Sepeda Motor}

Untuk melihat kecenderungan penggunaan sepeda motor pada usia di bawah 17 tahun di lingkungan tempat tinggal repsonden, maka responden diberi pertanyaan terkait hal tersebut. Berdasarkan jawaban responden, diketahui bahwa mayoritas responden $(50,8 \%)$ menyatakan bahwa di lingkungan tempat tinggalnya terdapat lebih dari 10 orang remaja di bawah usia 17 tahun yang telah dapat mengendarai sepeda motor. Selanjutnya dapat dilihat pada Tabel 8. 
Tabel 8. Remaja usia dibawah 17 tahun di lingkungan tempat tinggal yang telah bisa mengendarai sepeda motor

\begin{tabular}{|l|c|c|}
\hline \multicolumn{1}{|c|}{ Respon } & Jumlah & Prosentase \\
\hline Tidak menjawab & 4 & 3,3 \\
\hline Tidak ada & 2 & 1,6 \\
\hline 1-4 orang & 20 & 16,4 \\
\hline 5-10 orang & 34 & 27,9 \\
\hline Lebih dari 10 orang & 62 & 50,8 \\
\hline
\end{tabular}

\subsubsection{Pembahasan}

Secara umum hasil dari survei kecenderungan berkendara pada remaja usia di bawah 17 tahun ini cukup memprihatinkan. Mayoritas responden sebanyak 80,3\% telah dapat mengendarai sepeda motor pada usia mereka yang masih kurang dari 17 tahun. Dari 63 orang responden siswa SMA, hanya tiga orang $(4,7 \%)$ saja yang belum dapat mengendarai sepeda motor. Lebih memprihatinkan lagi, dari tiga orang tersebut, dua orang menyatakan keinginan untuk belajar mengendarai sepeda motor pada saat ini. Masifnya penggunaan sepeda motor pada usia yang masih dini ini juga didukung oleh data bahwa menurut mayoritas responden $(50,8 \%)$ terdapat lebih dari 10 orang remaja di bawah usia 17 tahun di lingkungan tempat tinggalnya yang telah dapat mengendarai sepeda motor.

Usia responden saat belajar sepeda motor untuk pertama kalinya mayoritas berada pada usia 12-13 tahun (masing-masing 28,6\%). Ada kecenderungan bahwa usia untuk belajar mengendarai sepeda motor untuk pertama kalinya semakin muda. Hal ini terlihat pada data bahwa responden berusia 16 tahun pertama kali belajar mengendarai sepeda motor pada usia 13 tahun, sedangkan responden dengan usia lebih muda pertama kali belajar mengendarai sepeda motor pada usia 11 tahun. Selain itu jumlah responden yang belajar mengendarai sepeda motor untuk yang pertama kalinya pada usia 12 tahun mengalami peningkatan pada usia responden yang lebih muda (13,6\%; $30 \%$; $50 \% ; 61,5 \%)$.

Frekuensi berkendara mayoritas reponden pada kategori sering, yaitu lebih dari empat kali dalam seminggu $(42,9 \%)$. Mayoritas reponden juga cenderung berkendara sampai di luar lingkungan tempat tinggal $(57,1 \%)$.

Dilihat dari jenis kelamin responden, laki-laki cenderung lebih berisiko dibandingkan dengan perempuan. Secara umum lebih banyak responden laki-laki yang telah dapat mengendarai sepeda motor dibandingkan dengan perempuan. Proporsi responden laki- 
laki yang telah dapat mengendarai sepeda motor sebanyak $88,7 \%$, sedangkan responden perempuan sebanyak $73,9 \%$.

Responden laki-laki juga cenderung belajar mengendarai sepeda motor untuk yang pertama kalinya pada usia yang lebih muda daripada responden perempuan. Mayoritas responden laki-laki belajar mengendarai sepeda motor untuk yang pertama kalinya pada usia 12 tahun (29,8\%), sedangkan responden perempuan pada usia 13 tahun $(29,4 \%)$. Selain itu prosentase responden yang belajar mengendarai sepeda motor untuk yang pertama kalinya pada usia 11 tahun juga berbeda, 19,1\% untuk responden laki-laki dan 13,7\% untuk repsonden perempuan.

Resiko yang dimiliki responden laki-laki juga terlihat dari frekuensi berkendara. Mayoritas responden laki-laki $(55,3 \%)$ berkendara lebih dari empat kali dalam seminggu. Ditambah lagi adanya kecenderungan yang diperlihatkan responden laki-laki, yaitu untuk berkendara sampai di luar lingkungan tempat tinggal. Mayoritas responden laki-laki $(63,8 \%)$ menyatakan bahwa mereka cenderung untuk berkendara keluar dari lingkungan tempat tingal mereka. Berbeda dengan responden perempuan, kecenderungan frekuensi dan jangkauan berkendara responden mereka lebih menyebar.

Seiring dengan bertambahnya usia juga bertambah pula resiko. Dilihat dari tingkat pendidikan, responden siswa SMA telah dapat mengendarai sepeda motor sebanyak $95 \%$, sedangkan responden siswa SMP sebanyak 65\%. Frekuensi berkendara responden siswa SMA juga lebih sering dibanding dengan siswa SMP. Mayoritas responden siswa SMA $(55,9 \%)$ berkendara lebih dari empat kali dalam seminggu, sedangkan mayoritas responden siswa SMP (38,5\%) berkendara kurang dari satu kali dalam seminggu. Berdasarkan jarak yang ditempuh dalam berkendara pun, responden siswa SMA lebih berisiko. Mereka cenderung berkendara di luar lingkungan tempat tinggal $(74,6 \%)$, sedangkan responden siswa SMP cedenrung berkendara di dalam lingkungan tempat tinggal $(69,2 \%)$.

Satu hal yang cukup melegakan adalah adanya kecenderungan responden yang belum bisa mengendarai sepeda motor untuk tidak berkeinginan untuk belajar mengendarainya pada saat ini. Untuk itu perlu diselidiki lebih lanjut, hal-hal apakah yang menunjang keteguhan hati mereka ini. 
Meskipun hasil survei ini sudah mencukupi sebagai bukti ilmiah cerminan kehidupan nyata terkait perilaku berkendara pada remaja usia di bawah 17 tahun, namun masih dibutuhkan studi lanjutan terkait keterbatasan jumlah responden. Agar mendapat gambaran yang lebih komprehensif diperlukan survei dengan cakupan responden yang lebih luas.

\section{PENUTUP}

Berdasarkan hasil penelitian, dapat disimpulkan bahwa gambaran perilaku berkendara pada respoden adalah sebagai berikut:

a. Mayoritas reponden $(80,3 \%)$ telah dapat mengendarai sepeda motor.

b. Mayoritas responden $(50,8 \%)$ terdapat lebih dari 10 orang remaja di bawah usia 17 tahun di lingkungan tempat tinggalnya yang telah dapat mengendarai sepeda motor.

c. Usia responden saat belajar sepeda motor untuk pertama kalinya mayoritas berada pada usia 12-13 tahun (masing-masing 28,6\%).

d. Ada kecenderungan bahwa usia untuk belajar mengendarai sepeda motor untuk pertama kalinya semakin muda.

e. Frekuensi berkendara mayoritas reponden pada kategori sering, yaitu lebih dari empat kali dalam seminggu (42,9\%).

f. Mayoritas reponden juga cenderung berkendara sampai di luar lingkungan tempat tinggal $(57,1 \%)$.

g. Responden laki-laki cenderung lebih berisiko dibandingkan perempuan.

h. Responden dengan usia atau tingkat pendidikan lebih tinggi lebih berisiko.

i. Responden yang belum bisa mengendarai sepeda motor cenderung untuk tidak berkeinginan untuk belajar mengendarainya pada saat ini.

\section{DAFTAR PUSTAKA}

Pemerintah Republik Indonesia. Undang-Undang No 22 Tahun 2009 Tentang Lalu Lintas dan Angkutan Jalan.

NHTSA. 2008. Traffic Safety Fact Young Driver. http: wwwnrd.nhtsa.dot.gov/Pubs/811169 (diakses 24 September 2014)

WHO. 2009. Global Satus Report On Safety. http://www.who.int/violence injury prevention/road safety status/2009/en/ (diakses 24 September 2014) 